\title{
Mechanisms of chloride secretion induced by thermostable direct haemolysin of Vibrio parahaemolyticus in human colonic tissue and a human intestinal epithelial cell line
}

\author{
A. TAKAHASHI, Y. SATO, Y. SHIOMI, V. V. CANTARELLI, T. IIDA, M. LEE* and T. HONDA
}

Department of Bacterial Infections, Research Institute for Microbial Diseases, Osaka University, 3-1, Yamadaoka, Suita, Osaka 565-0871 and*Department of Urology, School of Medicine, University of Kobe, 7-5-1 Kusunoki, Tyuoku, Kobe, Hyogo 650-0017, Japan

\begin{abstract}
Thermostable direct haemolysin (TDH) produced by Vibrio parahaemolyticus is thought to play an important role in the severe diarrhoea caused by this organism. This study investigated the enterotoxicity of TDH for human intestinal cells. Addition of TDH to the mucosal side of human colonic tissue in Ussing chambers caused increased short circuit currents (Isc), a process that was inhibited by $4,4^{\prime}$-diisothiocyanatostilbene-2,2' disulphonic acid (DIDS), an inhibitor of $\mathrm{Ca}^{2+}$-activated chloride $\left(\mathrm{Cl}^{-}\right)$channels. With human colonic epithelial (Caco-2) cells, high Isc and intracellular $\mathrm{Ca}^{2+}$ concentrations $\left(\left[\mathrm{Ca}^{2+}\right]_{\text {in }}\right)$ were detected after the addition of $\mathrm{TDH}$ to the apical side of the cell monolayer. The Isc decreased with the addition of DIDS, but not with glybenclamide, 5nitro-2-(3-phenylpropylamino) benzoic acid, or gadolinium chloride. No Isc increase with TDH was observed when the $\mathrm{Cl}^{-}$in the medium was replaced by gluconate or when $\mathrm{Ca}^{2+}$ was depleted. Similarly, TDH did not raise $\left[\mathrm{Ca}^{2+}\right]_{\text {in }}$ after depletion of extracellular $\mathrm{Ca}^{2+}$. R7, a mutant form of TDH, reduced the effects of TDH on Isc and $\left[\mathrm{Ca}^{2+}\right]_{i n}$, as did protein kinase $\mathrm{C}$ (PKC) inhibitors. Thus, TDH increases $\mathrm{Cl}^{-}$secretion in human colonic epithelial cells, apparently through mechanisms involving cell binding and $\mathrm{Ca}^{2+}$ influx, followed by elevation of $\left[\mathrm{Ca}^{2+}\right]_{\text {in }}$ associated with PKC phosphorylation.
\end{abstract}

\section{Introduction}

Vibrio parahaemolyticus is an important cause of gastro-enteritis. Clinically, the infection is characterised by diarrhoea and abdominal pain which generally subside after 7-10 days. However, the mechanisms underlying the diarrhoeic action of this pathogen are not well understood. Thermostable direct haemolysin (TDH) secreted from V. parahaemolyticus is considered to be a major virulence factor of this organism [1]. It has various biological activities including haemolytic activity, cardiotoxicity, mouse lethality and enterotoxicity $[1-4]$. Several reports have shown that TDH is able to induce intestinal secretion in animal models and that it is involved in the pathogenesis of diarrhoea induced by $V$. parahaemolyticus [5-7]. However, the precise mode of action of this toxin in the pathogenesis

Received 9 Aug. 1999; revised version accepted 31 Jan. 2000.

Corresponding author: Dr A. Takahashi (e-mail: akiratak@ nutr.med.tokushima-u.ac.jp). of intestinal disease has yet to be established. Huntley et al. [8] have shown that the intracellular $\mathrm{Ca}^{2+}$ concentration $\left(\left[\mathrm{Ca}^{2+}\right]_{\text {in }}\right)$ in erythrocytes is increased by $\mathrm{TDH}$ along with an increase in cation influx. TDH also induces chloride $\left(\mathrm{Cl}^{-}\right)$-dependent extracellular ion transport in rabbit ileum with $\mathrm{Ca}^{2+}$ as a second messenger [6]. On the other hand, addition of TDH to the apical side of T84 cells, a colonic crypt-like cell line, did not stimulate either $\mathrm{Cl}^{-}$secretion or an increase in $\left[\mathrm{Ca}^{2+}\right]_{\text {in }}[9]$.

It has been suggested that the haemolytic effect of TDH is initiated by binding to the erythrocyte surface and subsequent pore formation in the membrane, resulting in colloid osmotic lysis [10]. It was not known whether the binding of TDH to cell receptors had a significant effect on Isc in the human colon. Although some reports have suggested that GT1b is the possible receptor for $\mathrm{TDH}[11,12]$, recent studies contradicted these findings $[1,13]$. R7, a mutant form of TDH, was included in the present study. This mutant toxin has a single amino acid substitution of serine for 
glycine at residue 62 , which markedly decreases its haemolytic activity, although it retains the ability to bind to erythrocytes and competes with native TDH for binding sites $[14,15]$. The present study investigated the mechanism of action of TDH on ion transport in human colonic cells.

\section{Materials and methods}

\section{Human colon tissue}

Human colon tissue was obtained from eight patients who underwent elective abdominal surgery at Kobe Rosai Hospital between Dec. 1998 and April 1999. All the patients consented to the use of tissue for this study. The study was conducted in accordance with the Declaration of Helsinki and approved by the Human Ethics Committee of Kobe Rosai Hospital. The diagnosis that necessitated removal of large intestine in these patients was carcinoma. Tissue samples were taken from macroscopically normal areas distant from the cancer lesion. They were prepared immediately by cutting the surgically resected colon open along the mesenteric border and then transporting the tissue in ice-cold modified Ringer's solution to the laboratory. The modified Ringer's solution contained: $120 \mathrm{mM} \mathrm{NaCl}$, $25 \mathrm{mM} \mathrm{NaHCO} 3,3.3 \mathrm{mM} \mathrm{KH} \mathrm{PO}_{4}, 0.8 \mathrm{mM} \mathrm{K} \mathrm{HPO}_{4}$, $1.2 \mathrm{mM} \mathrm{CaCl}_{2}$ and $10 \mathrm{mM}$ glucose. The $\mathrm{pH}$ of this solution was 7.4 when gassed with a mixture of $\mathrm{O}_{2} 95 \%$ and $\mathrm{CO}_{2} 5 \%$ at $37^{\circ} \mathrm{C}$. Before mounting in the Ussing chamber, the specimens were prepared by dissecting the muscle layers with fine scissors and forceps.

\section{Cells}

Caco-2 cells were purchased from the American Type Culture Collection (Rockville, MD, USA). Caco-2 cells were derived originally from a human colon carcinoma and develop villus-like structures during growth to confluence. They were maintained in Eagle's Minimum Essential Medium (MEM) supplemented with fetal bovine serum (FBS) 10\%, gentamicin $100 \mathrm{U} / \mathrm{ml}$ and non-essential amino acids $1 \%$. The media and supplements were from Gibco BRL (Gaithersburg, MD, USA). Cells were grown in $75-\mathrm{ml}$ flasks at $37^{\circ} \mathrm{C}$ in air with $\mathrm{CO}_{2} 5 \%$, fed at 2-day intervals and passaged weekly. Stock cells were trypsinised, suspended at $20 \times 10^{4}$ cells $/ \mathrm{ml}$ in medium and seeded at confluent density on to $1.0-\mathrm{ml}$ transwell inserts (Costar, Cambridge, MA, USA). After 3 days, $2 \mathrm{mM}$ sodium butyrate (Sigma) was added. The cells on transwell inserts were used for the Ussing chamber experiments after culture for 6 days. Sodium butyrate is known to induce differentiation in many cells, including Caco-2 cells [16-18]. It occurs naturally in normal human colon and is used as an energy source by colonocytes [19]. Levels of butyrate in normal human faeces may be as high as $20 \mathrm{mM}$ [20]. Caco-2 cells treated with butyrate have higher trans-epithelial resistances and greater sensitivity to trans-epithelial short circuit current (Isc) increases by TDH compared with nontreated cells (A. Takahashi and T. Honda, unpublished observations). Thus, butyrate-treated Caco-2 cells were used in this study to investigate the effects of TDH.

\section{Ussing chamber experiments}

For measurement of Isc, the bath solution contained modified Ringer's solution, $\mathrm{pH}$ 7.4. To deplete $\mathrm{Ca}^{2+}$ from the apical cell surface, $\mathrm{CaCl}_{2}$ was omitted from the bath solution and $1 \mathrm{mM}$ EGTA was added. Apical $\mathrm{Cl}^{-}$current was measured following permeabilisation of the basolateral membrane with nystatin $360 \mu \mathrm{g} / \mathrm{ml}$ for 15-30 min to establish a mucosa-to-serosa $\mathrm{Cl}^{-}$ concentration gradient. Serosal $\mathrm{NaCl}$ was replaced by equimolar sodium gluconate and $\mathrm{CaCl}_{2}$ was increased to $4 \mathrm{mM}$ to compensate for the $\mathrm{Ca}^{2+}$-buffering capacity of the gluconate ion [21]. The nystatin-induced pores provide electrical continuity without loss or alteration of cytoplasmic compounds necessary for the maintenance of the response to acetylcholine and $\left[\mathrm{Ca}^{2+}\right]_{\text {in }}$ [22]. Transwell cell culture inserts were mounted in an Ussing chamber (laboratory made) and the tissues were continuously short-circuited. Trans-epithelial resistance was measured by applying a $5-\mathrm{mV}$ pulse at $40-50-\mathrm{s}$ intervals and the resistance was calculated by Ohm's law. TDH (prepared as described below), 4,4'-diisothiocyanatostilbene-2,2'-disulphonic acid (DIDS), glybenclamide, 5-nitro-2-(3-phenylpropylamino) benzoic acid (NPPB) and gadolinium chloride (all from Sigma) were added only to the mucosal bath solution at the concentrations indicated.

\section{Isolation of crude haemolysin}

Recombinant plasmids of pKK223-3 harbouring the structural genes of wild-type TDH (pT101) and mutant toxin R7 (pTI102) were introduced into Escherichia coli JM109 by transformation. Transformed E. coli were cultivated at $37^{\circ} \mathrm{C}$ for $16 \mathrm{~h}$ with rotary shaking in Luria-Bertani broth (Bacto tryptone, Difco, 1\%, yeast extract, Difco, $0.5 \%$ and $\mathrm{NaCl} 0.5 \%$ ) containing ampicillin $100 \mu \mathrm{g} / \mathrm{ml}$. The recombinant toxins were purified as reported previously [23] with minor modifications. Briefly, the harvested cells were treated with polymyxin (Wako Pure Chemicals, Osaka, Japan) $3000 \mathrm{U} / \mathrm{ml}$ in $10 \mathrm{mM}$ phosphate-buffered saline (PBS; $\mathrm{pH}$ 7.2) to release the periplasmic components. The proteins were further purified through a series of chromatography columns. Fractions containing wildtype TDH and R7 were assayed by haemolysis on rabbit blood agar plates [24]. The purity of samples was examined by SDS-PAGE according to the method of Laemmli [25], in polyacrylamide $12 \%$ gels with $2 \mu \mathrm{g}$ of protein per lane.

\section{Intracellular $\mathrm{Ca}^{2+}$}

The concentration of $\left[\mathrm{Ca}^{2+}\right]_{\text {in }}$ was determined by microfluorimetry with a fluorescent dye, 1-(2-(5'- 
carboxyoxazol-2'-yl)-6-aminobenzofuran-5-oxy)-2(2' amino-5'-methylphenoxy)ethane-N,N, $\mathrm{N}^{\prime}, \mathrm{N}^{\prime}$-tetra-acetic acid, penta-acetoxy methyl ester (Fura-2/AM, Molecular Probes, Eugene, OR, USA), at excitation wavelengths of 340 and $380 \mathrm{~nm}$ and an emission wavelength of $510 \mathrm{~nm}$, with a specially designed chamber and an ARGUS-50/CA fluorimeter system (Hamamatsu Photonicus, Japan). The cells were cultured on glass coverslips $(18 \times 18 \mathrm{~mm})$ for 5 days, then loaded with Fura-2/AM $(2 \mu \mathrm{M})$ for $30 \mathrm{~min}$ and washed twice in PBS. The coverslips were then inserted into the chamber of the fluorimeter and recordings were taken within $30 \mathrm{~min}$.

\section{Statistical evaluations}

The data were evaluated by the unpaired Student's $t$ test and $\mathrm{p}<0.05$ was considered significant.

\section{Other chemicals}

Protein kinase $\mathrm{C}$ (PKC) inhibitors, calphostin $\mathrm{C}$ and staurosporin, were purchased from Sigma. Inorganic salts of guaranteed grade were purchased from Wako Pure Chemicals.

\section{Results}

Purification of $T D H$ and $R 7$

Wild-type and mutant TDH (R7) synthesised in E. coli JM109 and purified gave single bands on SDS-PAGE (Fig. 1a), suggesting that the toxins were purified to homogeneity. These samples were concentrated to $300 \mu \mathrm{g} / \mathrm{ml}$ by ultrafiltration through a PM10 membrane (Amicon) and stored in PBS at $4^{\circ} \mathrm{C}$. TDH displayed haemolytic activity on rabbit blood agar (Fig. 1b), while R7 did not, confirming an earlier report [15].

\section{Effects of TDH on human colon}

Addition of TDH caused an increase in Isc in human colonic tissue when added on the mucosal side of human colonic tissue in Ussing chambers (Fig. 2). The Isc did not change when PBS was added. The high Isc induced by TDH decreased when $100 \mu \mathrm{M}$ DIDS, an inhibitor of $\mathrm{Ca}^{2+}$-activated $\mathrm{Cl}^{-}$channels $[26,27]$, was added. These results suggest that TDH increases $\mathrm{Cl}^{-}$ secretion by human colonic tissues.

\section{Effects of TDH on a human colonic cell line}

The mechanism of ion secretion was further investigated with human colonic epithelial (Caco-2) cells. Fig. 3 shows that TDH increased the trans-epithelial current when added to the apical side of the Caco-2 cell monolayer. When the $\mathrm{Cl}^{-}$in the bath solution was substituted by gluconate on both the apical and basolateral sides of the cells, there was no increase in Isc irrespective of TDH addition (Fig. 3). This
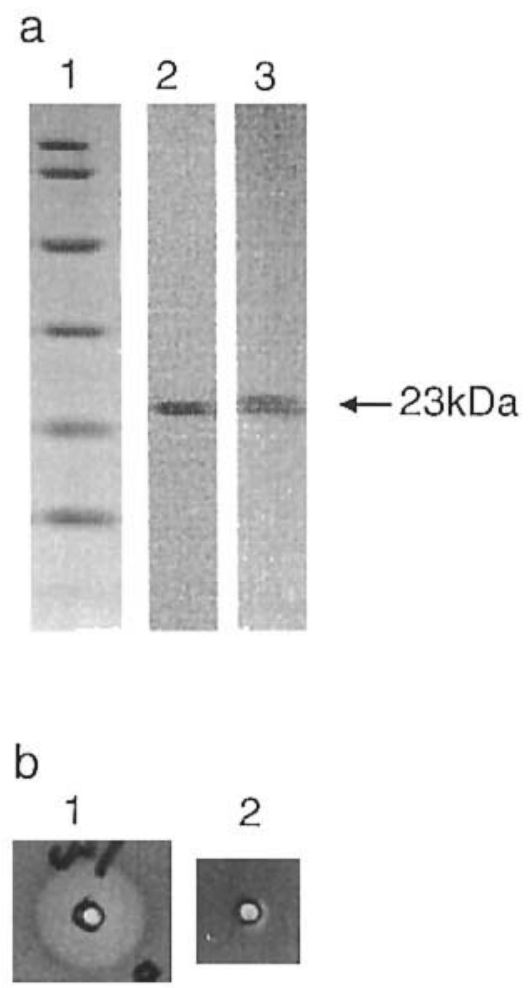

Fig. 1. (a) SDS-PAGE of purified preparations of wildtype TDH and mutant toxin R7. Lanes: 1, molecular mass markers (from top to bottom, 97.4, 66.3, 30.0, 20.1, $14.4 \mathrm{kDa}$ ); 2, wild-type TDH; 3, R7. (b) Haemolytic activity of (1) wild-type TDH and (2) R7 on rabbit blood agar.

indicates that the Isc stimulated by TDH is dependent on extracellular $\mathrm{Cl}^{-}$. When $\mathrm{Ca}^{2+}$ was removed from the bath solution by omission of $\mathrm{CaCl}_{2}$ and addition of $1 \mathrm{mM}$ EGTA, the addition of TDH again caused no change in Isc (Fig. 3). Thus, Isc changes are also dependent on the extracellular $\mathrm{Ca}^{2+}$, suggesting that the increase in Isc stimulated by TDH is generated by $\mathrm{Ca}^{2+}$-activated $\mathrm{Cl}^{-}$channels.

The current increased in a dose-dependent manner according to the concentration of TDH (Fig. 4a). Transepithelial resistance did not change with TDH concentrations ranging from 0.01 to $10 \mu \mathrm{g} / \mathrm{ml}$ (Fig. 4b). On the other hand, trans-epithelial resistance decreased markedly at a TDH concentration of $50 \mu \mathrm{g} / \mathrm{ml}$, making it difficult to short-circuit the cell monolayers and increasing the current measurement noise. As no appreciable trans-epithelial resistance change was noted with $10 \mu \mathrm{g}$ of $\mathrm{TDH} / \mathrm{ml}$, this concentration was used for subsequent experiments.

\section{Effects of $\mathrm{Cl}^{-}$channel inhibitors}

Four kinds of channel inhibitors were used to investigate the hypothesis that the Isc increase stimulated by $\mathrm{TDH}$ is generated by $\mathrm{Ca}^{2+}$-activated $\mathrm{Cl}^{-}$channels. Fig. 5a shows that the Isc increase in 


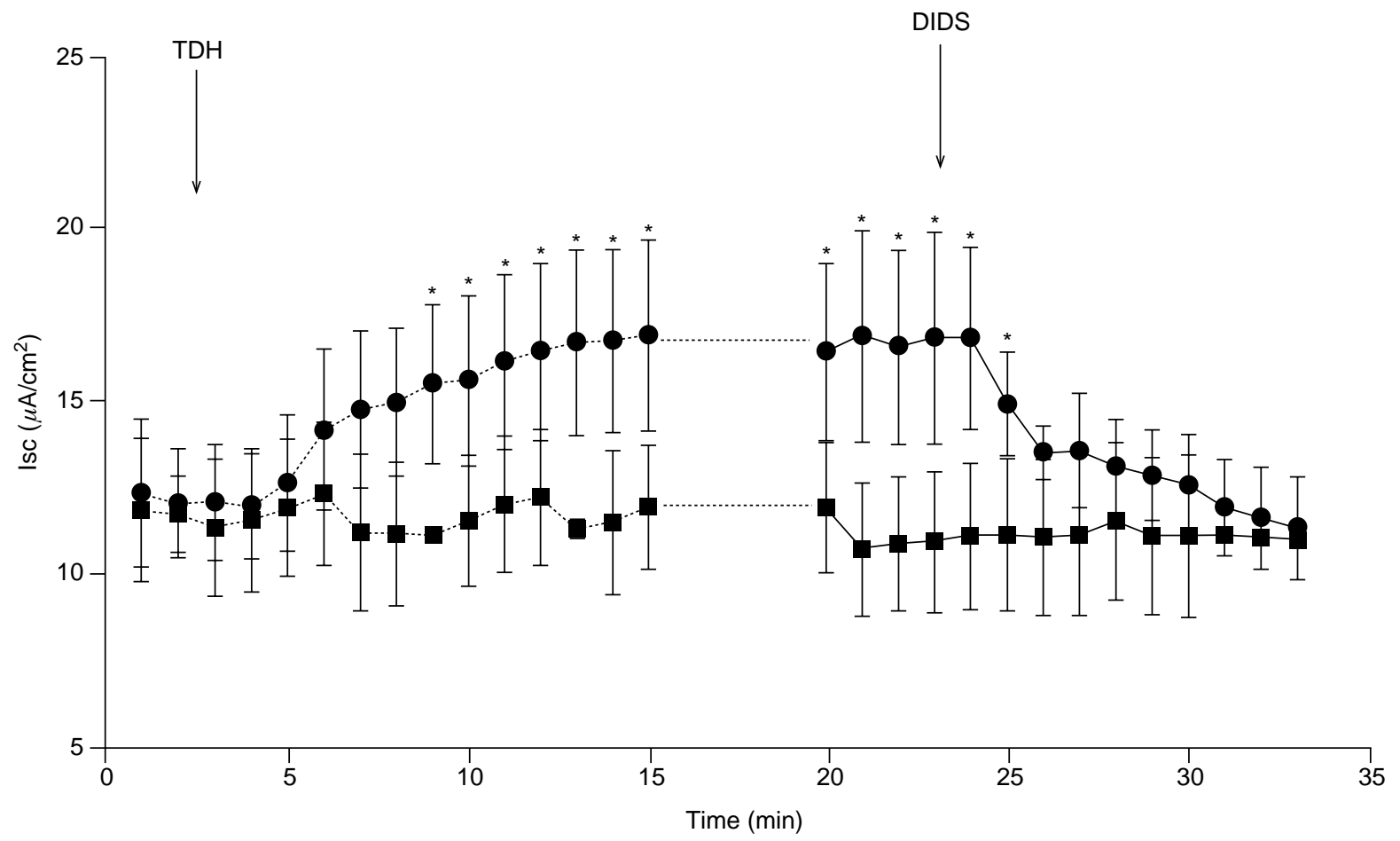

Fig. 2. Effects of TDH $10 \mu \mathrm{g} / \mathrm{ml}$ and $100 \mu \mathrm{M}$ DIDS on Isc of human colon tissue mounted in Ussing chambers: TDH was added on the mucosal side of the tissue; after 20-25 min, DIDS was added to the mucosal side of the human colon tissue at the time indicated. $\mathbf{\square}$, negative control (no TDH or DIDS added). Values are expressed as means and SD $(\mathrm{n}=5)$. ${ }^{*}$ Significant difference, $\mathrm{p}<0.05$ versus negative control.

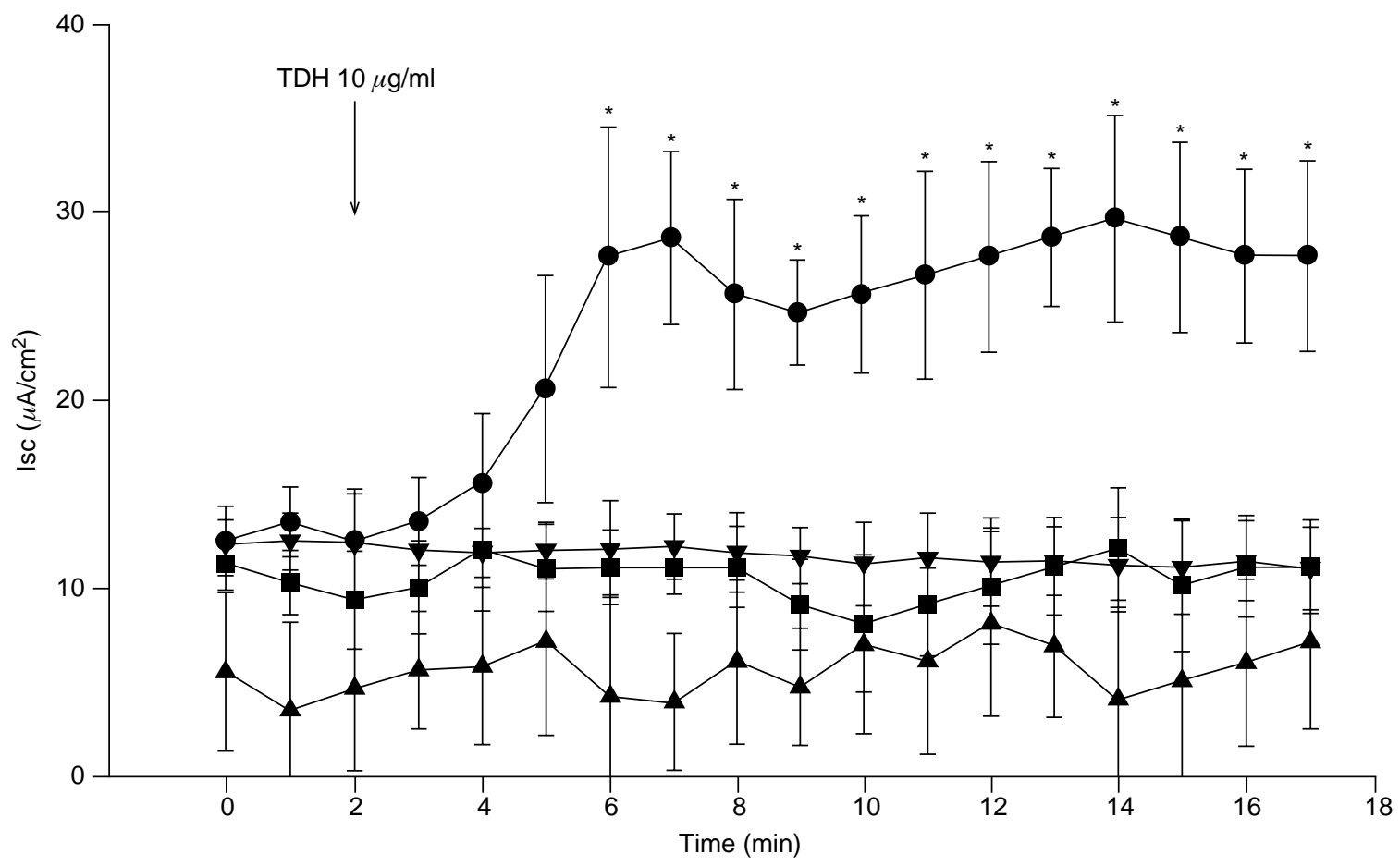

Fig. 3. Effect of gluconate and $\mathrm{Ca}^{2+}$ depletion on Isc in Caco-2 cell monolayers treated with TDH. $\bullet$, positive control (TDH challenge); $\mathbf{\square}, \mathrm{Cl}^{-}$in the bath solution of the Ussing chamber was replaced by gluconate; $\boldsymbol{\Delta}, \mathrm{Ca}^{2+}$ depletion $\left(\mathrm{CaCl}_{2}\right.$ was omitted from the bath solution and $1 \mathrm{mM}$ EGTA was added). TDH $10 \mu \mathrm{g} / \mathrm{ml}$ was added on the apical side of the Caco-2 cells at the time indicated. $\nabla$, negative control (no TDH added). Values are expressed as means and SD $(\mathrm{n}=5)$. ${ }^{*}$ Significant difference, $\mathrm{p}<0.05$ versus negative control. 

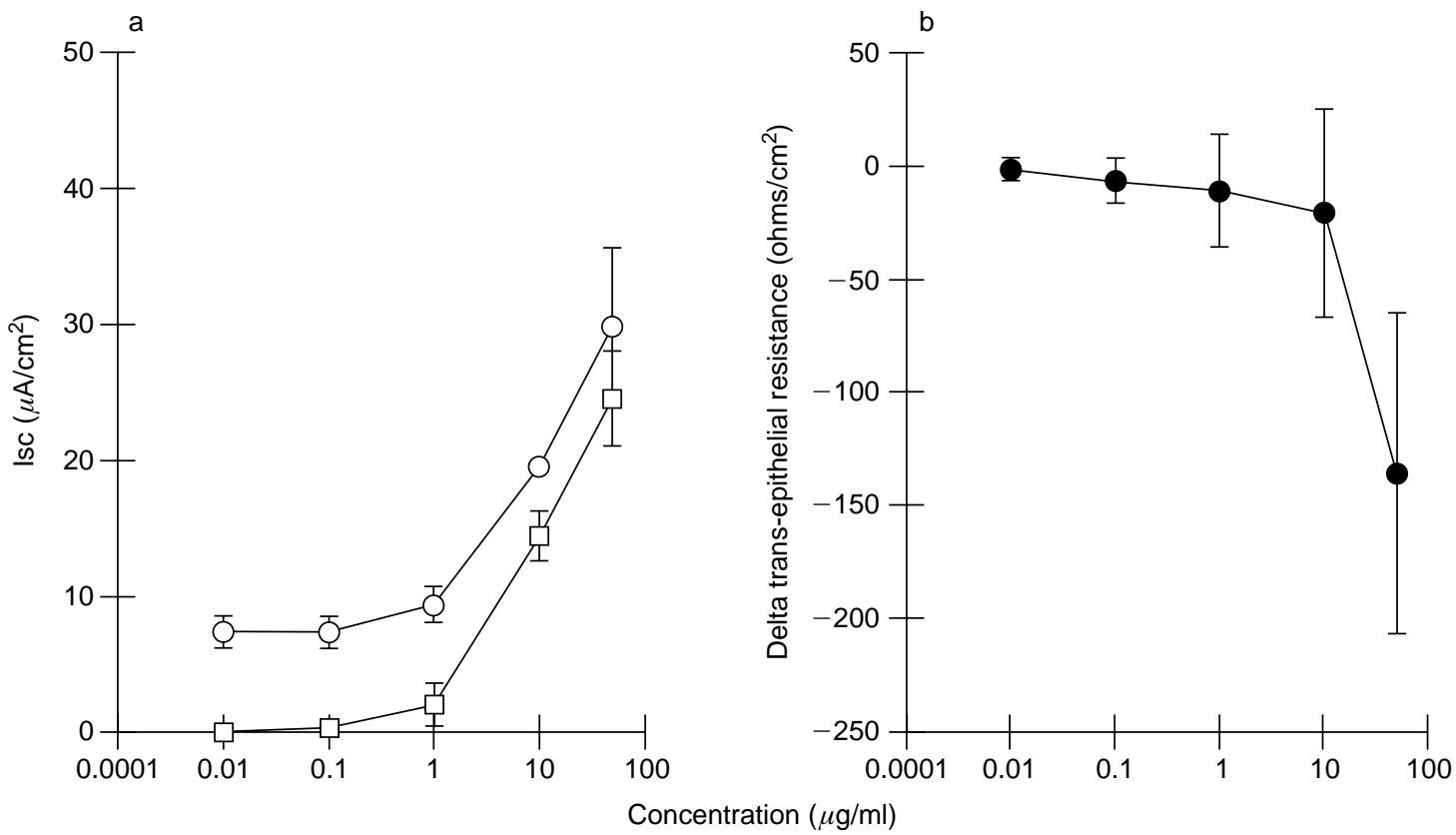

Fig. 4. Effect of TDH concentration on Isc and trans-epithelial resistance of Caco-2 cell monolayers. TDH was added to the basolateral side of Caco-2 cells mounted in Ussing chambers $(\mathrm{n}=6)$. (a) $\bigcirc$, peak Isc at 20 min after challenge with TDH; $\square$, Isc increase, compared with basal Isc. (b) Effect of TDH on trans-epithelial resistance. (Delta transepithelial resistance $=$ trans-epithelial resistance at $20 \mathrm{~min}$ after TDH addition - trans-epithelial resistance before TDH addition).

Caco-2 monolayers stimulated by TDH was inhibited by DIDS $(100 \mu \mathrm{M})$, an inhibitor of $\mathrm{Ca}^{2+}$-activated $\mathrm{Cl}^{-}$ channels [26, 27]. When Caco-2 cell samples were pretreated with DIDS, TDH had no effect on Isc (Fig. 5a). Glybenclamide $(300 \mu \mathrm{M})$, an inhibitor of cAMPdependent $\mathrm{Cl}^{-}$channels [28, 29], $100 \mu \mathrm{M} \mathrm{NPPB}$, an inhibitor of $\mathrm{Cl}^{-}$channels $[26,28]$ and gadolinium ${ }^{3+}$, an inhibitor of the stretch-activated channel [30,31], had no effect on TDH-induced increases in Isc (Fig. 5c). These results are consistent with the conclusion that Isc changes produced by TDH are generated by $\mathrm{Ca}^{2+}$. activated $\mathrm{Cl}^{-}$channels [32].

When the $\mathrm{Cl}^{-}$from the apical side of the bath solution was replaced by gluconate and the basolateral cell membranes were permeabilised by treatment with nystatin, TDH caused an increase in Isc that again was inhibited when DIDS was added on the apical side (Fig. 5b). This indicates that the $\mathrm{Ca}^{2+}$-activated $\mathrm{Cl}^{-}$ channel in the apical side of the Caco-2 cell monolayers generates the Isc increases stimulated by TDH.

\section{Effects of $R 7$ on Isc}

If binding of TDH to its receptor on Caco- 2 cells is a necessary step in altering Isc, there would be no change in Isc if TDH was prevented from binding to its receptor. R7, a mutant form of TDH [15], was used to check this possibility. The presence of R7 by itself had no effect on Isc, but when cells were pre-treated with R7, the effects of TDH on Isc were prevented (Fig. 6).

\section{Effects of PKC inhibitors on ISC}

PKC inhibitors were also used to evaluate the changes in Isc caused by TDH (Fig. 7). Compared with the positive control, $1 \mu \mathrm{M}$ calphostin $\mathrm{C}$ decreased the Isc by $69 \%$ and $0.01 \mu \mathrm{M}$ staurosporin by $74 \%$ at $21 \mathrm{~min}$ (Fig. 7). Calphostin $\mathrm{C}$ and staurosporin were pre-loaded for $30 \mathrm{~min}$. If pre-loaded for longer, trans-epithelial resistance decreased, making it difficult to measure the Isc.

\section{Changes in intracellular $\mathrm{Ca}^{2+}$ concentrations}

The intracellular $\mathrm{Ca}^{2+}$ concentration of Caco- 2 cells increased in the presence of TDH (Fig. 8a) but not in the absence of extracellular $\mathrm{Ca}^{2+}$. Thus, the increase in $\left[\mathrm{Ca}^{2+}\right]_{\text {in }}$ caused by TDH was due to an influx of $\mathrm{Ca}^{2+}$ from the extracellular medium. Pre-treatment of Caco-2 cells with mutant toxin $\mathrm{R} 7$ reduced the effects of $\mathrm{TDH}$ on $\mathrm{Ca}^{2+}$ influx (Fig. 8b). As already reported, R7 competes with TDH for binding sites [15], and the specific binding of TDH to its receptor was shown here to be necessary to increase $\left[\mathrm{Ca}^{2+}\right]_{\text {in }}$. The increase in $\left[\mathrm{Ca}^{2+}\right]_{\text {in }}$ caused by TDH was much less pronounced when calphostin $\mathrm{C}$ and staurosporin were added (Fig. $8 \mathrm{c}$ ), suggesting a PKC-mediated increase of $\left[\mathrm{Ca}^{2+}\right]_{\text {in }}$.

\section{Discussion}

The results show that TDH stimulated Isc currents in Caco-2 cells, a human colonic epithelial cell line, and 
a
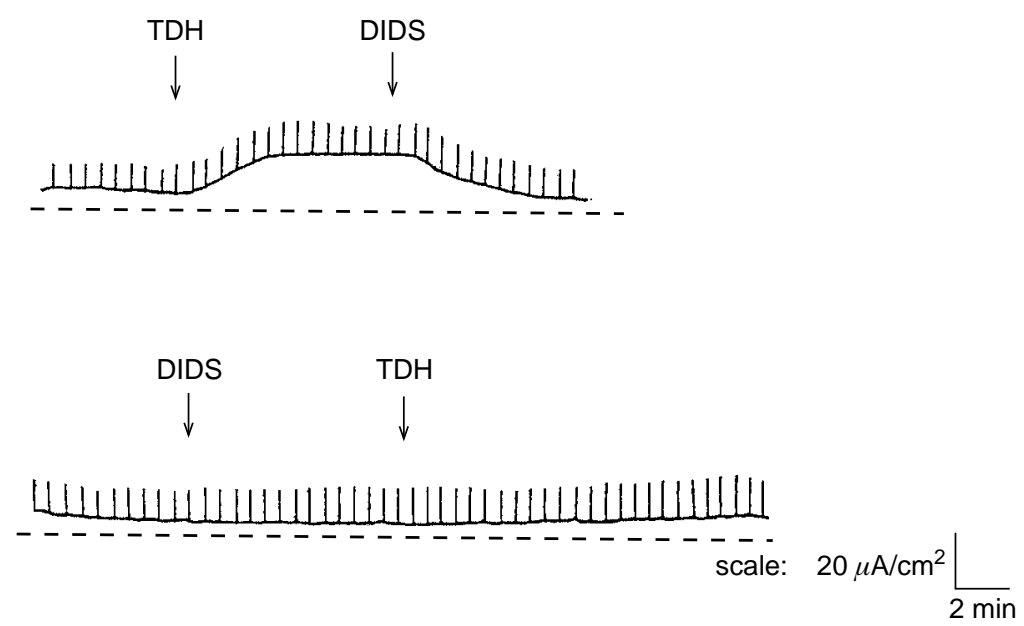

b
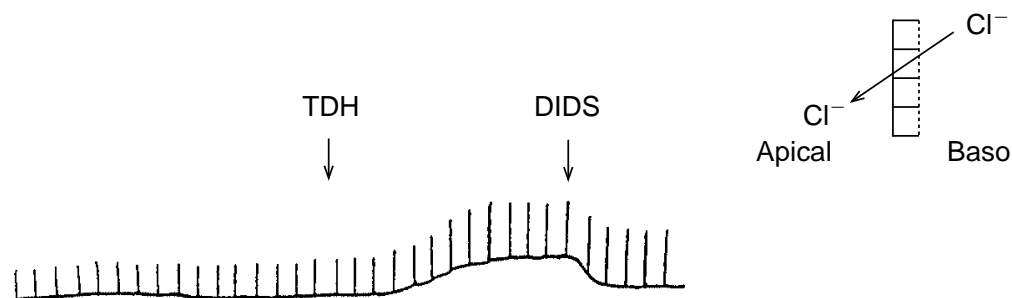

scale: $\quad 20 \mu \mathrm{A} / \mathrm{cm}^{2} \underset{\mid}{2 \min }$

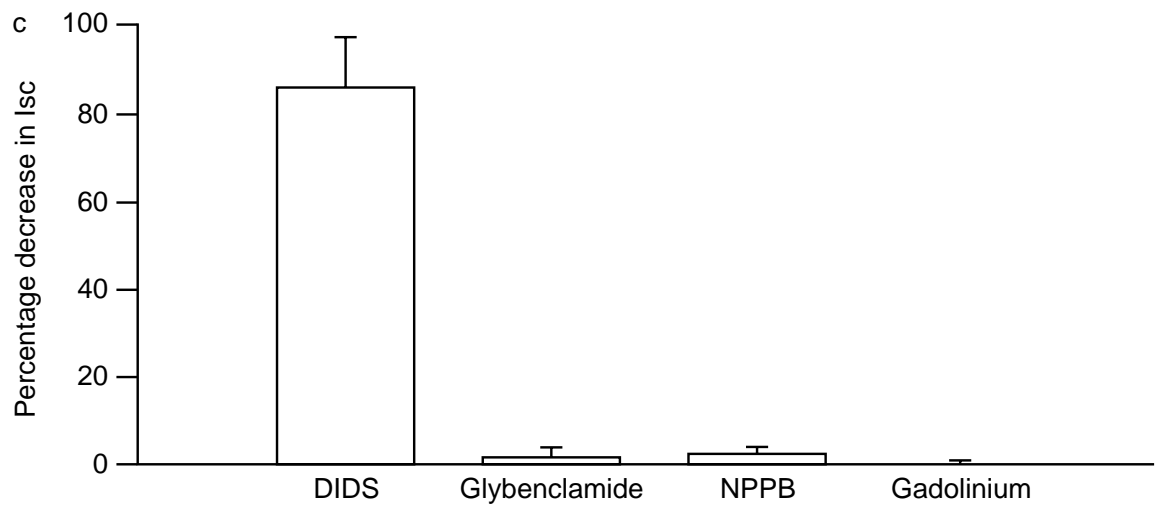

Fig. 5. Effect of inhibitors on Isc in Caco-2 cell monolayers in the presence of TDH. TDH $10 \mu \mathrm{g} / \mathrm{ml}$ was added on the apical side at the time indicated. (a) Isc traces showing effect of $100 \mu \mathrm{M}$ DIDS added on the apical side at the time indicated. (b) Effects of TDH and DIDS on apical membrane $\mathrm{Cl}^{-}$currents after the establishment of a basolateral-toapical $\mathrm{Cl}^{-}$gradient and permeabilisation of the basolateral membrane with nystatin. The illustration on the right represents the monolayers and indicates the direction of the ion gradient (arrow) and the permeabilised membrane (broken line). (c) Effect of $\mathrm{Cl}^{-}$channel inhibitors, $100 \mu \mathrm{M}$ DIDS, $300 \mu \mathrm{M}$ glybenclamide, $100 \mu \mathrm{M}$ NPPB and $500 \mu \mathrm{M}$ gadolinium ${ }^{3+}$, on the Isc $\left(14.2 \pm 2.8 \mu \mathrm{A} / \mathrm{cm}^{2}\right)$ stimulated by TDH $10 \mu \mathrm{g} / \mathrm{ml}$. The $\mathrm{Cl}^{-}$channel inhibitors were added to the apical side of the cell monolayers after stimulation with $\mathrm{TDH}$ for $10 \mathrm{~min}$. The percentage decrease in Isc= (Inhibited Isc) $/($ Peak Isc - Basal Isc) $\times 100$. Basal Isc, Isc before TDH addition; Peak Isc, the highest Isc during $10 \mathrm{~min}$ after TDH addition; Inhibited Isc, the lowest Isc during $10 \mathrm{~min}$ after addition of $\mathrm{Cl}^{-}$channel inhibitors. Values are expressed as means and $\mathrm{SD}(\mathrm{n}=5)$. 

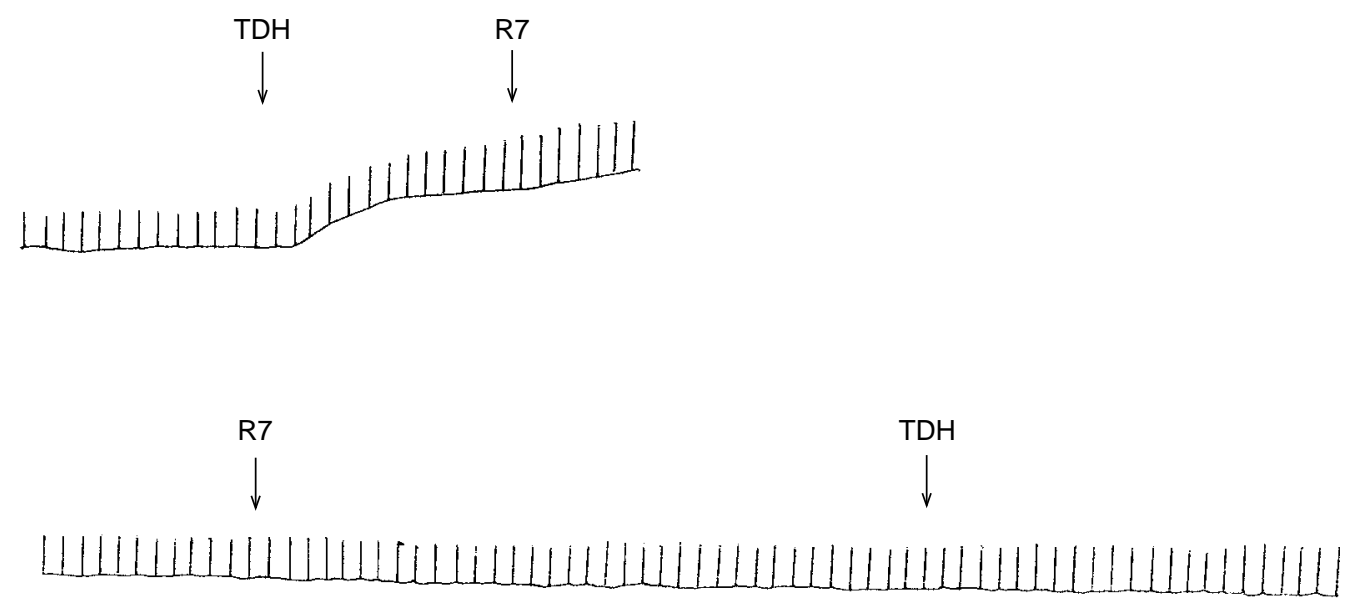

$$
\text { scale: } \quad 25 \mu \mathrm{A} \frac{\mid}{2 \min }
$$

Fig. 6. Isc traces showing the effect of mutant toxin R7 on Isc in Caco-2 cell monolayers. TDH $10 \mu \mathrm{g} / \mathrm{ml}$ and R7 $50 \mu \mathrm{g} / \mathrm{ml}$ were added to the apical side at the times indicated.

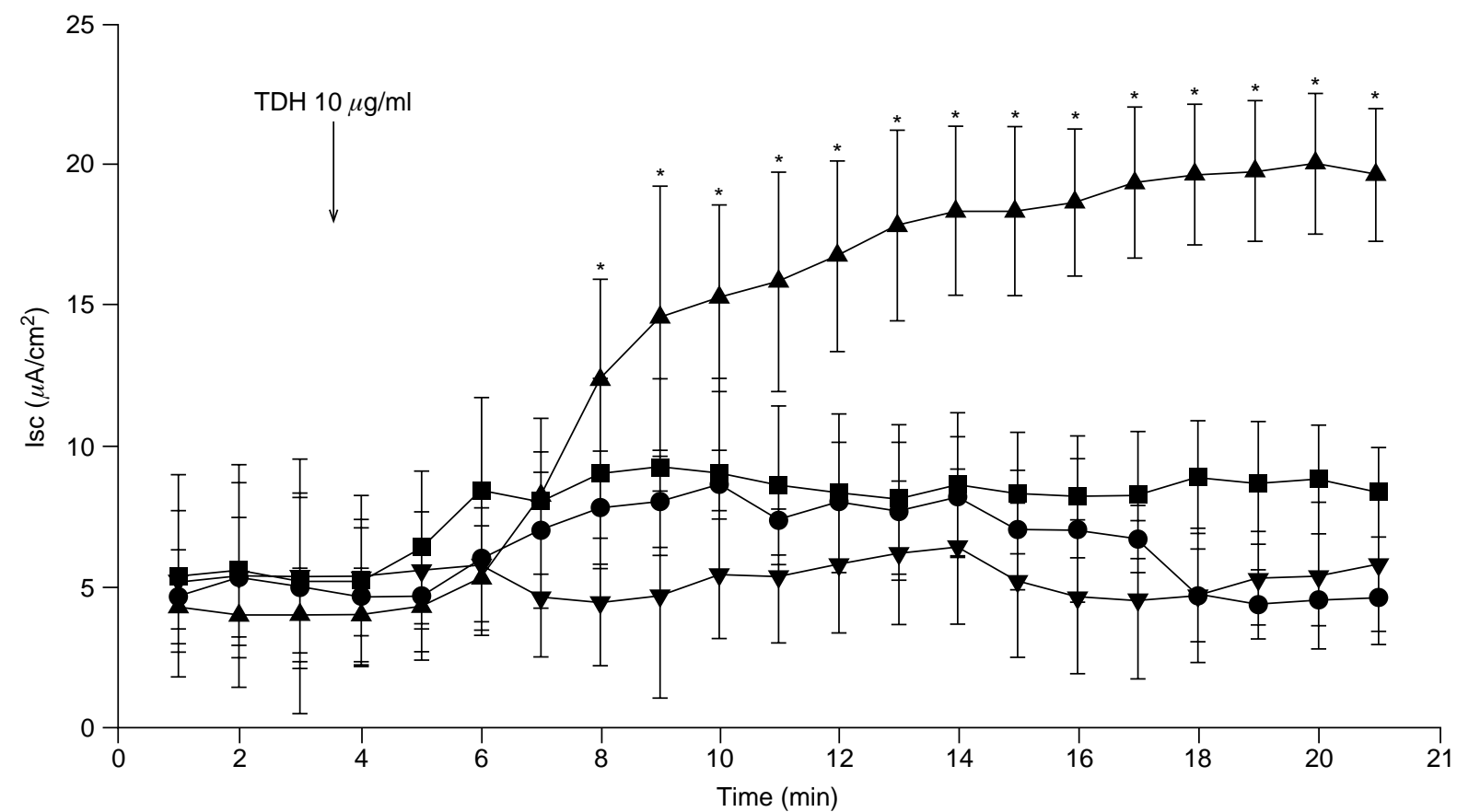

Fig. 7. Effect of PKC inhibitors on Isc in Caco-2 cell monolayers. TDH $10 \mu \mathrm{g} / \mathrm{ml}$ was added on the apical side at the time indicated. 0 , pre-treated with $0.01 \mu \mathrm{M}$ staurosporin for $30 \mathrm{~min}$; $\mathbf{\square}$, pre-treated with $1 \mu \mathrm{M}$ calphostin $\mathrm{C}$ for 30 min; $\boldsymbol{\Delta}$, positive control (no pre-treatment); $\boldsymbol{\nabla}$, negative control (no TDH added). Values are expressed as mean and SD $(\mathrm{n}=5) .{ }^{*}$ Significant difference, $\mathrm{p}<0.05$ versus negative control.

these currents followed the activation of $\mathrm{Cl}^{-}$channels. Isc increases caused by addition of $\mathrm{TDH}$ to the mucosal side of the human colonic tissue had the same characteristics as those observed with Caco-2 cells, suggesting that TDH may also stimulate $\mathrm{Cl}^{-}$ secretion in the human colon.

TDH is a pore-forming toxin creating a functional pore size of c. $2 \mathrm{~nm}$ in target membranes [10]. Thus, there is the possibility that $\mathrm{Cl}^{-}$moves through TDH-formed pores. However, other evidence suggests that this is not the case: DIDS, calphostin $\mathrm{C}$ and staurosporin inhibited the TDH-induced $\mathrm{Cl}^{-}$currents. If $\mathrm{Cl}^{-}$was simply passing through TDH-formed pores, those inhibitors would have no inhibitory effect on the $\mathrm{Cl}^{-}$currents.

Human colonic epithelial cells are reported to have several types of $\mathrm{Cl}^{-}$secretion pathways [33]. It was not 

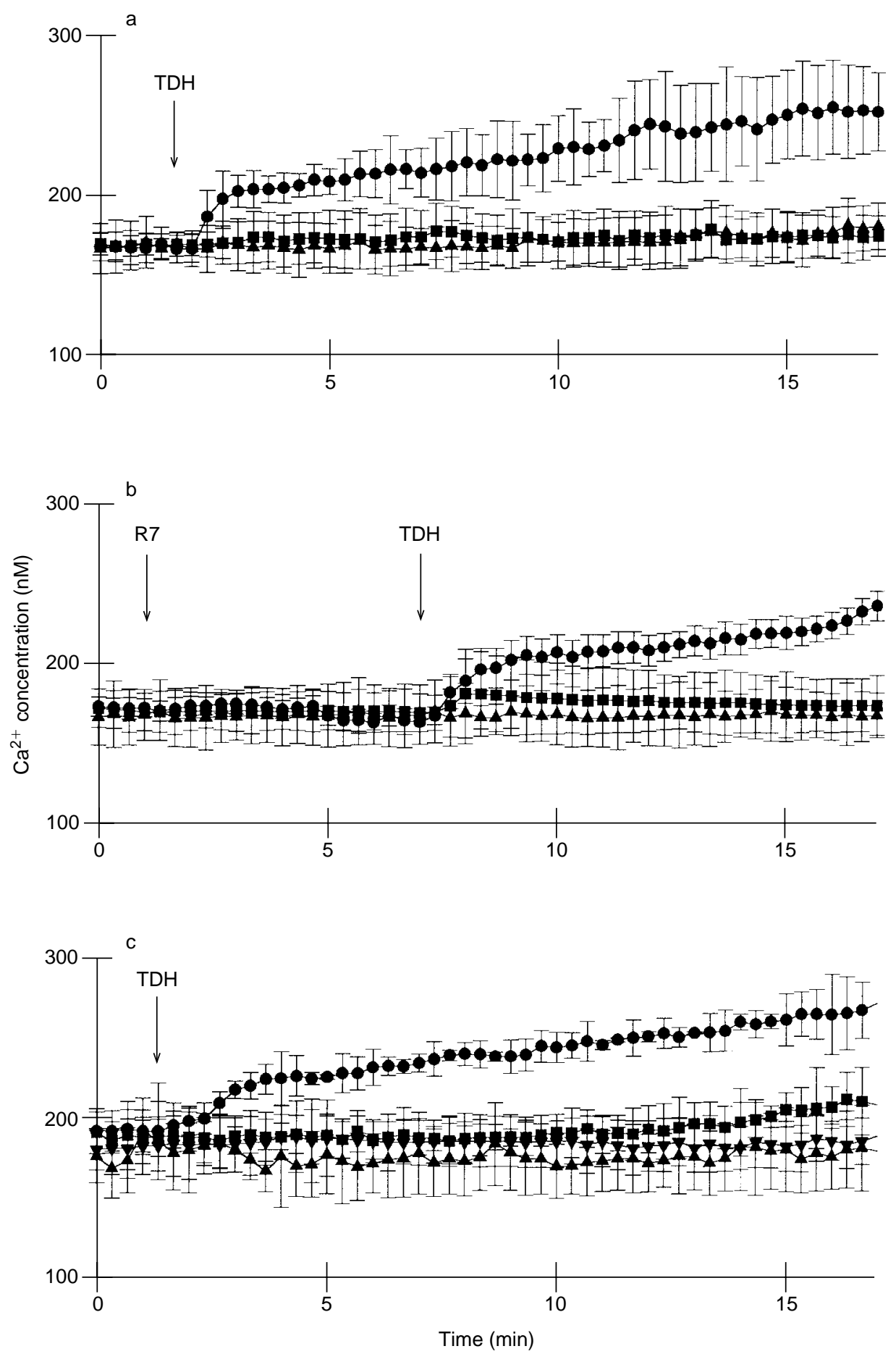

Fig. 8. Changes in intracellular free $\mathrm{Ca}^{2+}$ concentration due to action of TDH on Caco-2 cell monolayers. TDH $10 \mu \mathrm{g} / \mathrm{ml}$ was added at the time indicated. (a) $\boldsymbol{\bullet}$, positive control (TDH added, monolayers in usual bath solution); $\mathbf{\square}$, $\mathrm{CaCl}_{2}$ was depleted and $1 \mathrm{mM}$ EGTA was added to the bath solution in the chamber of the fluorimeter. TDH was added at the time indicated. $\boldsymbol{\Delta}$, negative control (TDH not added). (b) $\bullet$, TDH $10 \mu \mathrm{g} / \mathrm{ml}$ was added at the time indicated (R7 not added). $\mathbf{\square}$, TDH $10 \mu \mathrm{g} / \mathrm{ml}$ and R7 $50 \mu \mathrm{g} / \mathrm{ml}$ were added at the times indicated. $\boldsymbol{\Delta}$, negative control (TDH and R7 not added). (c) $\bigcirc$, positive control: TDH only. $\mathbf{\square}$, pre-treated with $0.01 \mu \mathrm{M}$ staurosporin for $30 \mathrm{~min}$ followed by TDH challenge. $\boldsymbol{\Delta}$, pre-treated with $1 \mu \mathrm{M}$ calphostin $\mathrm{C}$ for $30 \mathrm{~min}$ followed by TDH challenge. $\boldsymbol{\nabla}$, negative control (TDH not added). Values are expressed as means and SD $(\mathrm{n}=10)$.

clear which type of $\mathrm{Cl}^{-}$secretion pathway was activated by TDH, but the cystic fibrosis transmembrane conductance regulator (CFTR) is one of the major $\mathrm{Cl}^{-}$channels in Caco-2 cells and is one of the most important $\mathrm{Cl}^{-}$secretion pathways involved in human diarrhoea. It was possible, therefore, that CFTR was the target for TDH, especially as PKC inhibitors were found to block $\mathrm{Cl}^{-}$secretion induced by TDH and PKC is said to activate CFTR [34]. However, glybenclamide and NPPB, both of which are known to 
be inhibitors of CFTR [28], had no effect on the $\mathrm{Cl}^{-}$ currents stimulated by TDH (Fig. 5c), indicating that TDH effects were not mediated by CFTR.

The swelling of erythrocytes or Intestine 407 cells induced by TDH has been reported $[10,35]$. If this type of cell swelling had occurred with Caco- 2 cells, there was the possibility that the stretch-activated channels may have been opened. Cell swelling was noted within $15 \mathrm{~min}$ of adding TDH (unpublished observation). However, gadolinium $^{3+}$, an inhibitor of stretch-activated channels, had no effect on TDH-stimulated $\mathrm{Cl}^{-}$ secretion and so these channels do not appear to be involved with $\mathrm{TDH}$-induced $\mathrm{Cl}^{-}$secretion.

Other investigators have reported that, in rabbit ileum, Isc increases due to TDH depend on extracellular $\mathrm{Cl}^{-}$, as indicated by increased transient Isc currents $[5,6]$. No self-inactivation of Isc was observed in the present work during the $30 \mathrm{~min}$ following the addition of TDH to the human colonic cells. These findings suggest that the $\mathrm{Cl}^{-}$currents induced by TDH are mediated by the $\mathrm{Ca}^{2+}$-activated $\mathrm{Cl}^{-}$channel, because there is evidence of $\left[\mathrm{Ca}^{2+}\right]_{\text {in }}$ dependency and DIDS, an inhibitor of the $\mathrm{Ca}^{2+}$-activated $\mathrm{Cl}^{-}$channel, reduced the Isc. It is also likely that the channels are located on the apical side of the cells (Fig. 5a and b).

There may be three steps for the stimulation of $\mathrm{Cl}^{-}$ currents by TDH. First, TDH binds to its receptor on the epithelial cells. This is suggested by the inhibition of $\left[\mathrm{Ca}^{2+}\right]_{\text {in }}$ elevation and $\mathrm{Cl}^{-}$current by $\mathrm{R} 7 . \mathrm{R} 7$ is a mutant form of TDH and inhibits the haemolytic activity of TDH through competitive binding to the receptor $[14,15]$. Consequently, the effect of TDH on $\mathrm{Cl}^{-}$secretion is also dependent on the binding of TDH to its receptors. Second, TDH induces an influx of $\mathrm{Ca}^{2+}$ followed by an elevation of $\left[\mathrm{Ca}^{2+}\right]_{\text {in. }}$. When extracellular $\mathrm{Ca}^{2+}$ was depleted, there was no $\left[\mathrm{Ca}^{2+}\right]_{\text {in }}$ elevation, suggesting that the influx of $\mathrm{Ca}^{2+}$ was TDHinduced. No $\left[\mathrm{Ca}^{2+}\right]_{\text {in }}$ spike was observed in the present study, as is reported to occur in rabbit cell lines $[6,36]$. Considering the pathway of $\mathrm{Ca}^{2+}$ influx, PKC inhibitors inhibited the $\mathrm{Ca}^{2+}$ influx stimulated by TDH. This suggests that TDH activates $\mathrm{PKC}$, which is then followed by the elevation of $\left[\mathrm{Ca}^{2+}\right]_{\text {in. }}$. The increase in $\left[\mathrm{Ca}^{2+}\right]_{\text {in }}$ caused by TDH was reduced by calphostin $\mathrm{C}$, while there was no increase at all with staurosporin. Calphostin $\mathrm{C}$ is a more specific inhibitor of $\mathrm{PKC}$, whereas staurosporin also inhibits others kinases. An earlier study reported that PKC may be involved in the lysis of human erythrocytes by TDH [37]. Taken together, these findings suggest that PKC activation induced by TDH may be an important step for inducing the diarrhoea caused by $V$. parahaemolyticus.

The third step is the stimulation of $\mathrm{Cl}^{-}$secretion mediated by $\left[\mathrm{Ca}^{2+}\right]_{\text {in }}$ elevation. When the $\left[\mathrm{Ca}^{2+}\right]_{\text {in }}$ elevation was suppressed by $\mathrm{R} 7$ or by depletion of the extracellular $\mathrm{Ca}^{2+}$, no $\mathrm{Cl}^{-}$current increases were seen.
Moreover, DIDS decreased the $\mathrm{Cl}^{-}$current without suppression of $\left[\mathrm{Ca}^{2+}\right]_{\text {in }}$ elevation (data not shown), pointing to the conclusion that increased $\mathrm{Cl}^{-}$currents were a secondary effect of increased $\left[\mathrm{Ca}^{2+}\right]_{\text {in }}$.

In conclusion, it is proposed that TDH may induce diarrhoea (i.e., fluid secretion) in three steps: (i) binding to the receptor molecule (not yet identified) on colonic epithelial cells, (ii) elevation of $\left[\mathrm{Ca}^{2+}\right]_{\text {in }}$ associated with PKC activation, and (iii) activation of $\mathrm{Ca}^{2+}$-activated $\mathrm{Cl}^{-}$channels, resulting in $\mathrm{Cl}^{-}$secretion from the serosal to the mucosal side of the epithelial layer.

We thank $\mathrm{Mr} \mathrm{H}$. Yamada for technical assistance and Drs $\mathrm{K}$. Nagayama and W. Yanagihara for helpful discussions. Dr K. Kawaguchi kindly provided human colonic tissues. This work was funded by a Grant-in-Aid for the 'Research for the Future' program of the Japan Society for the Promotion of Science (JSPS-RFJF 97L00704).

\section{References}

1. Honda T, Iida T. The pathogenicity of Vibrio parahaemolyticus and the role of the thermostable direct haemolysin and related haemolysins. Rev Med Microbiol 1993; 4: 106-113.

2. Takeda Y. Thermostable direct hemolysin of Vibrio parahaemolyticus. Methods Enzymol 1988; 165: 189-193.

3. Goshima K, Owaribe H, Yamanaka H, Yoshino S. Requirement of calcium ions for cell degeneration with a toxin (vibriolysin) from Vibrio parahaemolyticus. Infect Immun 1978; 22: $821-832$.

4. Sakurai J, Honda T, Jinguji Y, Arita M, Miwatani T. Cytotoxic effect of the thermostable direct hemolysin produced by Vibrio parahaemolyticus on FL cells. Infect Immun 1976; 13: 876-883.

5. Nishibuchi M, Fasano A, Russell RB, Kaper JB. Enterotoxigenicity of Vibrio parahaemolyticus with and without genes encoding thermostable direct hemolysin. Infect Immun 1992; 60: $3539-3545$.

6. Raimondi F, Kao JPY, Kaper JB, Guandalin S, Fasano A. Calcium-dependent intestinal chloride secretion by Vibrio parahaemolyticus thermostable direct hemolysin in a rabbit model. Gastroenterology 1995; 109: 381-386.

7. Sakazaki R, Tamura K, Nakamura A, Kurata T, Ghoda A, Kazuno Y. Enteropathogenic activity of Vibrio parahaemolyticus. In: Fujino T, Sakaguchi G, Sakazaki R, Takeda T (eds) International Symposium on Vibrio parahaemolyticus. Tokyo, Saikon. 1974: 231-235.

8. Huntley JS, Hall AC. Aspects of the haemolytic reaction induced by Kanagawa haemolysin of Vibrio parahaemolyticus. Toxicon 1994; 32: 1397-1412.

9. McEwan GTA, Brown ADA, Hirst BH, Simmons NL. Kanagawa haemolysin of Vibrio parahaemolyticus stimulates transepithelial $\mathrm{Cl}^{-}$secretion in human intestinal T84 epithelial cell layers. J Physiol 1994; 475: 92.

10. Honda T, Ni Y, Miwatani T, Adachi T, Kim J-K. The thermostable direct hemolysin of Vibrio parahaemolyticus is a pore-forming toxin. Can J Microbiol 1992; 38: 1175-1180.

11. Takeda Y, Takeda $T$, Honda $T$, Miwatani $T$. Inactivation of the biological activities of the thermostable direct hemolysin of Vibrio parahaemolyticus by ganglioside GT1. Infect Immun 1976; 14: 1-5.

12. Takeda Y, Takeda T, Honda T, Sakurai N, Ohtomo N, Miwatani T. Inhibition of hemolytic activity of the thermostable direct hemolysin of Vibrio parahaemolyticus by ganglioside. Infect Immun 1975; 12: 931-933.

13. Douet JP, Castroviejo M, Dodin A, Bébéar C. Study of the haemolytic process and receptors of thermostable direct haemolysin from Vibrio parahaemolyticus. Res Microbiol 1996; 147: 687-696.

14. Iida T, Tang G-Q, Suttikulpitug S, Yamamoto K, Miwatani T, Honda T. Isolation of mutant toxins of Vibrio parahaemolyticus 
hemolysin by in vitro mutagenesis. Toxicon 1995; 33 : 209-216.

15. Tang G-Q, Iida T, Yamamoto K, Honda T. A mutant toxin of Vibrio parahaemolyticus thermostable direct hemolysin which has lost hemolytic activity but retains ability to bind erythrocytes. Infect Immun 1994; 62: 3299-3304.

16. Augeron C, Laboisse CL. Emergence of permanently differentiated cell clones in a human colonic cancer cell line in culture after treatment with sodium butyrate. Cancer Res 1984; 44: 3961-3969.

17. Jacewicz MS, Acheson DWK, Mobassaleh M, Donohue-Rolf A Balasubramanian KA, Keusch GT. Maturational regulation of globotriaosylceramide, the Shiga-like toxin 1 receptor, in cultured human gut epithelial cells. J Clin Invest 1995; 96: 1328-1335.

18. Matsumoto H, Erickson RH, Gum JR, Yoshioka M, Gum E, Kim YS. Biosynthesis of alkaline phosphatase during differentiation of the human colon cancer cell line Caco-2. Gastroenterology 1990; 98: 1199-1207.

19. Scheppach W. Effects of short chain fatty acids on gut morphology and function. Gut 1994; 35 Suppl 1: S35-S38.

20. Cummings JH, Pomare EW, Branch WJ, Naylor CPE, Macfarlane GT. Short chain fatty acids in human large intestine, portal, hepatic and venous blood. Gut 1987; 28: 1221-1227.

21. Anderson MP, Welsh MJ. Calcium and cAMP activate different chloride channels in the apical membrane of normal and cystic fibrosis epithelia. Proc Natl Acad Sci USA 1991; 88: 6003-6007

22. Horn R, Marty A. Muscarinic activation of ionic currents measured by a new whole-cell recording method. $J$ Gen Physiol 1988; 92: 145-159.

23. Yoh M, Honda T, Miwatani T, Nishibuchi M. Characterization of thermostable direct hemolysins encoded by four representative $t d h$ genes of Vibrio parahaemolyticus. Microb Pathog 1991; 10: 165-172

24. Iida $\mathrm{T}$, Yamamoto $\mathrm{K}$. Cloning and expression of two genes encoding highly homologous hemolysins from Kanagawaphenomenon-positive Vibrio parahaemolyticus T-4750 strain. Gene 1990; 93: 9-15.

25. Laemmli UK. Cleavage of structural proteins during the assembly of the head of bacteriophage T4. Nature 1970; 227: $680-685$.
26. Cunningham SA, Warrell RT, Benos DJ, Frizzell RA. cAMPstimulated ion currents in Xenopus oocytes expressing CFTR cRNA. Am J Physiol 1992; 262: C783-C788.

27. Inoue $\mathrm{CN}$, Woo JS, Schwiebert EM et al. Role of purinergic receptors in chloride secretion in Caco-2 cells. Am J Physiol 1997; 272: C1862-C1870.

28. Schultz BD, Singh AK, Devor DC, Bridges RJ. Pharmacology of CFTR chloride channel activity. Physiol Rev 1999; 79: S109-S144.

29. Sheppard DN, Welsh MJ. Inhibition of the cystic fibrosis transmembrane conductance regulator by ATP-sensitive $\mathrm{K}^{+}$ channel regulators. Ann NY Acad Sci 1993; 707: 275-284.

30. Chen Y, Simasko SM, Niggel J, Sigurdson WJ, Sachs F. $\mathrm{Ca}^{2+}$ uptake in GH3 cells during hypotonic swelling: the sensory role of stretch-activated ion channels. Am J Physiol 1996; 270: C1790-C1798.

31. Garrill A, Tyerman SD, Findlay GP. Ion channels in the plasma membrane of protoplasts from the halophytic angiosperm Zostera muelleri. J Membr Biol 1994; 142: 381-393.

32. Schwiebert EM, Egan ME, Hwang T-H et al. CFTR regulates outwardly rectifying chloride channels through an autocrine mechanism involving ATP. Cell 1995; 81: 1063-1073.

33. Fasano A. Cellular microbiology: can we learn cell physiology from microorganisms? Am J Physiol 1999; 276: C765-C776.

34. Gadsby DC, Nairn AC. Control of CFTR channel gating by phosphorylation and nucleotide hydrolysis. Physiol Rev 1999; 79: $\mathrm{S} 77-\mathrm{S} 107$

35. Tang G-Q, Iida T, Yamamoto K, Honda T. $\mathrm{Ca}^{2+}$-independent cytotoxicity of Vibrio parahaemolyticus thermostable direct hemolysin (TDH) on Intestine 407, a cell line derived from human embryonic intestine. FEMS Microbiol Lett 1995; 134 233-238

36. Fabbri A, Falzano L, Frank $\mathrm{C}$ et al. Vibrio parahaemolyticus thermostable direct hemolysin modulates cytoskeletal organization and calcium homeostasis in intestinal cultured cells. Infect Immun 1999; 67: 1139-1148.

37. Yoh M, Tang G-Q, Iida T, Morinaga N, Noda M, Honda T. Phosphorylation of a $25 \mathrm{kDa}$ protein is induced by thermostable direct hemolysin of Vibrio parahaemolyticus. Int $J$ Biochem Cell Biol 1996; 28: 1365-1369. 